\title{
Secondary School Principals' Perceptions of the Influence of KEMI Programmes on Leadership Competence Levels in Two Counties in Kenya
}

\section{Kombo, D. K., Department of Educational Founda- tions, Kenyatta University \\ Kalai, J. M., Department of Educational Admini- stration and Planning, University of Nairobi \\ Sang, A. K., Department of Curriculum Instruction and Educational Management, Egerton University}

\section{Abstract}

Adequate preparation and professional development is imperative for institutional leaders and managers particularly those in the education sector with a view to equipping professionals with requisite knowledge, skills and attitudes to function to the required competency levels. The Ministry of Education (Kenya) has been spending large amounts of money on development of educational managers, through its management training agency Kenya Education Management Institute (KEMI). For instance, in 2006 the annual management training budget was KShs. 250 million (Kenya Education Staff Institute, 2006). The budget is likely to have 
gone up owing to inflation rates and escalating living standards. This study sought to analyse the influence of KEMI management training on secondary school principals' management practices in their administrative task areas in Kenya. The study also sought to determine whether significant differences existed in principals' management practices scores between principals exposed to management training and those who had not been exposed to KEMI management training. The study also sought to determine whether principals' management practices scores differed significantly based on school categories (provincial and district schools). The findings indicated significant differences in principals' management practices based on exposure to management training by KEMI, and those not exposed to such training programmes. In particular, principals exposed to KEMI management training exhibited higher scores in all administrative tasks while all principals cited challenges in financial management, legal aspects in education and resource management. Principals in provincial schools indicated having more of the best practices in management than their counterparts in district and private schools. 


\section{Introduction}

Scholars, policy makers and practitioners in education underscore the imperatives of effective and efficient governance and leadership in educational institutions as a vehicle for realising institutional effectiveness as well as realising national development goals and aspirations (Republic of Kenya, 1988; Mbiti, 2007; Griffins, 1995; Republic of Kenya, 1999). Effective governance is imperative to enable developing countries to realise their national goals of education as well as international commitments such as the Millennium Development Goals (MDGs). Translating the national goals of education into a reality demands strategic planning and governance at institutional and policy making levels. Studies on governance and management of secondary schools have pointed out managerial and operational deficiencies (Morumbasi, 1993; Koech, 1994; Wachira, 1996; Kalai, 1998; Republic of Kenya-Koech Report, 1999). Other scholars such as Onyango (2001), Wachira (1996), Koech (1994) and Kalai (1998) attribute managerial and governance underperformance in secondary schools to appointment of principals without systematic preparation for their managerial roles. In addition, governance of secondary schools is constantly affected by the 
socio-economic dynamics and global economic trends and environments as well as dwindling resources which make it difficult for principals to perform their roles as expected without adequate preparation.

Given the foregoing scenario, a need existed to determine trends in educational management practices in secondary schools. Alleged cases of mismanagement and misappropriation of funds have been cited in the Kenyan setting (Republic of Kenya, 1988, 1998; Karani, et al. 1995 \& Daily Nation July 4, 1998). Some of the management and administrative shortcomings have occurred even among some of the head-teachers who had been exposed to in-service training organised by Kenya Education Staff Institute (KESI) and some of those who have been attending annual head-teachers' conferences.

Professional and research findings tend to cite a high correlation between the nature of management offered by the principals and the quality of results in national examinations (Asunda, 1983; Njuguna, 1998; Nxumalo, 1992 \& Okoth, 2000). Similarly, Eshiwani (1983) in a study on factors influencing performance of primary and secondary 
schools noted that some head-teachers who were heavily involved in private business mainly mismanaged schools due to divided attention and hence their schools performed poorly. Furthermore, in a study on secondary school principals' leadership styles and students' performance in Kenya Certificate of Secondary Education in Nairobi, Okoth (2000) established that in schools where principals were more democratic, the results were significantly different from institutions where principals were autocratic. Moreover, Okoth noted that schools whose principals had undergone management training performed significantly better than those schools where principals were not exposed to such training. Kariuki (1998) indicated that leadership tends to be a determining factor on academic performance in secondary schools, a factor supported by Griffin (1994) and Olembo, Wanga and Karagu (1992).

\section{Statement of the Problem}

Kenyans are now very conscious of the quality of services that they receive from public offices and other places where they seek services regularly, including from principals of secondary schools. The keenness on the quality of services could be attrib- 
uted to mass media exposure, levels of education and public campaigns that have been carried out in the last few years during public service weeks organised by the Ministry of Public Service. Such campaigns have underscored that "quality service is every citizen's right". Although KEMI uses a lot of funds for leadership development programmes, feedback on what principals think of the effects of such programmes is not conclusive. While the rating of KEMI leadership programmes among principals is unanimous that such programmes are useful, the extent to which principals appreciate their role in enhancing their leadership competencies is a matter of conjecture (Morumbasi, 1993; Kalai, 1998 \& Onyango, 2001). Given that principals provide direction on provision of quality education, it was imperative that their perceptions of the KEMI leadership programmes be established particularly in areas that have scarcity of resources like the Aridand Semi-Arid Areas (ASAL) where resource mobilisation poses a major challenge to principals. It is in the light of the foregoing that this study sought to analyse the secondary school principals' perceptions of the influence of Kenya Education Management Institute (KEMI) leadership development programmes on leadership competence levels in Machakos and Kitui Counties, Kenya. 


\section{Objectives of the Study}

To realise the purpose of the study, the following objectives were formulated:

a) To analyse secondary school principals' perceptions of the influence of Kenya Education Management Institute (KEMI) leadership programmes on their levels of competence in:

i) Curriculum and instruction

ii) Student personnel

iii) Physical facilities and

iv) Financial management in Kenya

b) To determine whether significant differences existed between principals exposed to KEMI leadership development programmes and those not exposed to such programmes on their perceptions of the influence of Kenya Education Management Institute (KEMI) leadership programmes on their levels of competence in:

i) Curriculum and instruction

ii) Student personnel 
iii) Physical facilities and

iv) Financial management in Kenya

c) To determine whether significant differences existed between secondary school principals in different school categories (provincial, district and private) on their perceptions of their levels of competence in:

i) Curriculum and instruction

ii) Student personnel

iii) Physical facilities and

iv) Financial management

\section{Research Design}

This study used the descriptive survey design, which according to Vyhmeister (2001), is appropriate for making reality known through collecting detailed factual information that describes existing phenomena at a given time. Survey research can also be used to examine effects of several groups at one time (Mertens, 2005). The data involved in this study focused on secondary school principals' perceptions on their levels of 
competence in their administrative task areas. The use of descriptive survey to establish status of things or conditions is supported by Mugenda and Mugenda (2003). The study was conducted in two counties (Kitui and Machakos Counties that now have sixteen districts).

\section{Target Population}

The study focused on 100 secondary schools in Machakos County (District Education Office, 2003) and 68 secondary schools in Kitui County (District Education Office, 2003) that had candidate classes - form four classes for the previous three years before the research was conducted, that is the year 2001 to 2003. These translated into 168 secondary school principals from whom respondents for the study were drawn.

\section{Sampling Size and Sampling Procedure}

A stratified proportionate sampling technique was used to obtain representative samples from three school categories of schools (private, district and provincials schools). The use of stratified proportionate sampling was informed by the fact that each of the schools had to have a 
number proportional to their strength in order to guarantee representative samples from each substratum. Twenty schools were chosen out of the 30 private secondary schools, while the rest were left out due to having not done twelfth grade examinations for three years consecutively (a requirement in the study). Forty-five district and 45 provincial schools were selected for this study, hence 110 secondary schools. This study contacted 88 schools with principals exposed to management training by Kenya Education Management Institute (KEMI) and 22 schools under principals not exposed to such programmes.

\section{Research Instruments}

This study used a self-appraisal report (an open-ended questionnaire), which had a number of sections. The first section focused on background information of the secondary school principals while six other subsequent sections focused on the six administrative task areas of principals. The self -appraisal report was validated through two ways. The first approach was through expert judgement of the thesis supervisor, a team of researchers referred to as Research and Recognition Committee. Thereafter, the instrument was 
subjected to content validity through a pilot study of five principals. Moreover, the Teachers' Service Commission Form "A" (S) was used to corroborate information obtained through self-appraisal report while interaction with students in counselling sessions helped verify part of the obtained data.

\section{Data Analysis Techniques}

Kerlinger (1986) defines data analysis as a statistical method used to analyse data so that it can be interpreted. Research analysis breaks down data into constituent parts to obtain answers to research questions. The Statistical Package for Social Sciences (SPSS version 11.5) was used to generate frequency tables, percentages, group means, test results and case summaries as per the rating norms of National Assessment and Accreditation Council, with minor modifications. The tests used for this study were: (i) One-way analysis of variance used to determine differences of group means between school categories, (ii) $\mathrm{T}$ test was used to compare educational management practices scores in secondary schools in the six management task areas between schools under principals exposed to management training by KESI and those without such exposure, (iii) By use 
of descriptive statistics, frequencies were tabulated and compared to indicate strengths and weaknesses of various practices. By adding the weight-ages of the six criteria, the institutional score was obtained. Schools that scored 55\% were rated as satisfactory in management practices.

\section{Discussion of the Study Findings}

The first objective of the study sought to analyse secondary school principals' perceptions of the influence of Kenya Education Management Institute (KEMI) leadership programmes on their levels of competence in curriculum and instruction. The comparison of T-test scores were as shown in Table 1.

Table 1: T-test for equality of means in principals' perceptions of their levels of competence curriculum and instruction based on exposure to KEMI

\begin{tabular}{|l|l|l|l|l|l|l|l|}
\hline & \multicolumn{9}{|c|}{ T-test for Equality of } & \multicolumn{3}{|l|}{$\begin{array}{l}\text { 95\% Confidence } \\
\text { interval of } \\
\text { the difference }\end{array}$} \\
\hline $\begin{array}{l}\text { Curriculum } \\
\text { and instruc- } \\
\text { tion }\end{array}$ & fig & (2-tailed) & $\begin{array}{l}\text { Mean } \\
\text { difference }\end{array}$ & $\begin{array}{l}\text { Std. Error } \\
\text { difference }\end{array}$ & Lower & Upper \\
\hline $\begin{array}{l}\text { Equal vari- } \\
\text { ances as- } \\
\text { sumed }\end{array}$ & $\mathbf{6}$ & 08 & 000 & -8.6727 & 1.58094 & - & \\
\hline
\end{tabular}

The findings indicated that the calculated $t$ (5.486) is greater than the tabulated $\mathrm{t}$ (1.980); 
hence it was held that significant differences existed in curriculum and instruction between schools under principals exposed to management training by KEMI and those not exposed to such training programmes. The findings suggest that exposure to leadership development programmes by KEMI had a significant difference on principals' perceptions of their level of competence in curriculum and instruction. Given that curriculum and instruction is the core business of any educational institution, such findings would suggest the necessity for leadership development of principals in the task area. However, the findings could also be attributed to availability of qualified teachers in public schools and principals' guidance, part of which stems from their experience and training in management among other factors.

Another objective sought to analyse secondary school principals' perceptions of the influence of KEMI leadership programmes on their levels of competence in student personnel or student welfare services. Table 2 shows the schools scores on perceived principals' competence levels in management of student welfare services. 
Table 2: Comparison of principals' perceptions KEMI leadership programmes on their levels of competence in student personnel / welfare services based on school categories

\begin{tabular}{|c|c|c|c|c|c|c|c|}
\hline & \multicolumn{4}{|c|}{ School categories: } & \multicolumn{3}{|c|}{$\begin{array}{l}\text { Exposure to Management } \\
\text { training by KEMI }\end{array}$} \\
\hline & $\begin{array}{l}\text { Private } \\
\text { Schools }\end{array}$ & $\begin{array}{l}\text { District } \\
\text { Schools }\end{array}$ & $\begin{array}{l}\text { Provin- } \\
\text { cial } \\
\text { School } \\
\text { s }\end{array}$ & Total: & No & Yes & Total: \\
\hline $\begin{array}{l}65.00 \\
- \\
74.99\end{array}$ & $\begin{array}{l}8 \\
(40.0 \%)\end{array}$ & $1(2.2 \%)$ & $0(.0 \%)$ & $\begin{array}{l}9 \\
(8.2 \%)\end{array}$ & $\begin{array}{l}7 \\
(31.8 \% \\
\end{array}$ & $2(2.3 \%)$ & $9(8.2 \%)$ \\
\hline $\begin{array}{l}75.00 \\
- \\
100.0 \\
0\end{array}$ & $\begin{array}{l}12 \\
(60.0 \%)\end{array}$ & $\begin{array}{l}44 \\
(97.8 \%)\end{array}$ & $\begin{array}{l}45 \\
(100.0 \\
\%)\end{array}$ & $\begin{array}{l}101 \\
(91.8 \% \\
\end{array}$ & $\begin{array}{l}15 \\
(68.2 \% \\
\end{array}$ & $\begin{array}{l}86 \\
(97.7 \%)\end{array}$ & $\begin{array}{l}101 \\
(91.8 \%)\end{array}$ \\
\hline Total & $\begin{array}{l}20 \\
(100.0 \\
\%)\end{array}$ & $\begin{array}{l}45 \\
(100.0 \% \\
)\end{array}$ & $\begin{array}{l}45 \\
(100.0 \\
\%)\end{array}$ & $\begin{array}{l}110 \\
(100.0 \\
\%)\end{array}$ & $\begin{array}{l}22 \\
(100.0 \\
\%)\end{array}$ & $\begin{array}{l}88 \\
(100.0 \\
\%)\end{array}$ & $\begin{array}{l}110 \\
(100.0 \%)\end{array}$ \\
\hline
\end{tabular}

The findings on students' welfare services corresponded with school categories both at the lowest scores and at the highest scores. Principals in provincial schools had the highest scores followed by district schools and finally the private schools. Similarly, schools under principals exposed to KESI in-service training programmes had higher percentages when compared by those schools under principals who were not exposed to in-service training programmes in students' welfare services. The services in question included planning for provision of guidance and counselling, health services, discipline, students' data management and ensuring that a holistic approach to student development in and out of school was adopted. The 
findings also correspond with the inferential statistics as reflected in table 3 .

Table 3: Analysis of Variance on principals' perceived levels of competence in management of student welfare services based on school categories

\begin{tabular}{|l|l|l|l|l|l|l|l|}
\hline $\begin{array}{l}\text { Student } \\
\text { welfare } \\
\text { services }\end{array}$ & $\begin{array}{l}\text { Sum of } \\
\text { Square } \\
\text { s }\end{array}$ & $\begin{array}{l}\text { De- } \\
\text { grees of } \\
\text { free- } \\
\text { dom } \\
\text { (df) }\end{array}$ & $\begin{array}{l}\text { Mean } \\
\text { Squa } \\
\text { re }\end{array}$ & Fig & & \\
\hline $\begin{array}{l}\text { Between } \\
\text { Groups }\end{array}$ & $\begin{array}{l}2120.50 \\
3\end{array}$ & & $\begin{array}{l}1060.2 \\
51\end{array}$ & $\begin{array}{l}114.7 \\
53\end{array}$ & $\begin{array}{l}\mathbf{0 0} \\
\mathbf{0}\end{array}$ & & \\
\hline $\begin{array}{l}\text { Within } \\
\text { Groups }\end{array}$ & 988.622 & 07 & 9.239 & & & \\
\hline Total & $\mathbf{3 1 0 9 . 1 2}$ & $\mathbf{0 9}$ & & & & \\
\hline
\end{tabular}

From Table 3, it is evident that the obtained $\mathrm{F}$ value (114.753) was greater than the critical value 3.07 with 2 and 107 degrees of freedom (df) at $5 \%$ level of significance. As such, this study held that significant differences existed in secondary schools principals' perceived levels of competence in management of student welfare services based on school categories. This was evident even in comparison of group means among school categories. The 20 private secondary schools had a group mean of 73.6694, while the 45 district schools had a group mean of 79.5878. The provincial schools had the highest mean of 85.6093 . 
The objective that sought to determine whether significant differences existed in principals' perceptions of their levels of competence in management of school plant (physical facilities), the findings were as presented in Table 4.

Table 4: Analysis of variance on principals' perceptions of their levels of competence in management of school facilities

\begin{tabular}{|c|c|c|c|c|c|}
\hline $\begin{array}{c}\text { Institutional } \\
\text { Percent } \\
\text { Criterion 4 }\end{array}$ & $\begin{array}{c}\text { Sum of } \\
\text { Squares } \\
\text { Between } \\
\text { Groups }\end{array}$ & $\begin{array}{c}\text { Degrees of } \\
\text { freedom } \\
\text { (df) }\end{array}$ & $\begin{array}{c}\text { Mean } \\
\text { Squar } \\
\text { e }\end{array}$ & F & Sig. \\
\hline $\begin{array}{c}\text { Within } \\
\text { Groups }\end{array}$ & 5411.485 .381 & 2 & 3243.1 & 64.127 & $\mathbf{0 0 0}$ \\
\hline Total & $\mathbf{1 1 8 9 7 . 8 6 6}$ & 107 & 50.575 & & \\
\hline
\end{tabular}

From Table 4, the obtained $F$ value (64.127) was greater than the critical value of 3.07 with 2 and 107 degrees of freedom (df) at 5 percent level of significance. As such, the study held that significant differences existed in secondary schools' educational management practices, in infrastructure and learning resources based on school categories. This was further evident even in pair wise comparison of group means among school categories. The 20 private secondary schools had a group mean of 54.5000, while the 45 district schools had a group mean of 55.0000. The provincial schools had the highest mean of 70.4603. The 
better facilities in provincial schools could be attributed to the resources pumped into such schools in terms of government assistance as well as the students' enrolment which could guarantee raising of the required development levies. This may not have been possible in some of the schools that were under-enrolled.

The next objective sought to determine whether significant differences existed in secondary school principals' levels of competence in school plant (facilities and learning resources) between schools under principals exposed to leadership development programmes by KEMI and those who lacked such exposure. To test further whether significant differences existed between the two groups, the two-tailed t-test was tabulated as shown in Table 5.

Table 5: T-test for equality of Means in principals' perceptions of their levels of competence in School plant based on exposure to KEMI

\begin{tabular}{|c|c|c|c|c|c|c|c|}
\hline \multirow[b]{2}{*}{$\begin{array}{l}\text { Institu- } \\
\text { tional } \\
\text { Percent }\end{array}$} & \multicolumn{5}{|c|}{ t-test for Equality of Means } & \multicolumn{2}{|c|}{$\begin{array}{l}95 \% \text { Confidence } \\
\text { Interval of the Differ- } \\
\text { ence }\end{array}$} \\
\hline & $\mathrm{T}$ & Df & $\begin{array}{l}\text { Sig. } \\
(2- \\
\text { tailed } \\
)\end{array}$ & $\begin{array}{l}\text { Mean } \\
\text { Differ- } \\
\text { ence }\end{array}$ & $\begin{array}{l}\text { Std. Error } \\
\text { Differ- } \\
\text { ence }\end{array}$ & Lower & Upper \\
\hline $\begin{array}{l}\text { Equal } \\
\text { variances } \\
\text { assumed }\end{array}$ & $\begin{array}{l}- \\
3.99 \\
7\end{array}$ & $\begin{array}{l}1 \\
0 \\
8\end{array}$ & .000 & -9.3344 & 2.33509 & $\begin{array}{l}-\overline{13.9629} \\
6\end{array}$ & 4.70587 \\
\hline
\end{tabular}


The findings of in Table 5 indicated that the calculated $\mathrm{t}$ (3.997) is greater than the tabulated $\mathrm{t}$ (1.980); hence it was held that significant differences existed in aggregate mean scores of schools in school plant between schools under principals exposed to leadership development programmes by KEMI and those not exposed to such programmes. Among the possible factors for the differences in the levels of facilities in schools could be economic ability of the school sponsors. Some of the mainstream churches such as the Catholic, the Presbyterian Church of East Africa and the Anglican Church of Kenya tend to have strong material support for their schools.

While this situation was true for the Catholic Church in the area of study, other denominations tended to confine their sponsorship to moral and spiritual development. Other possible factors for differences in school facilities could be the date of school establishment, the school categories and principals' level of innovation. The date of establishment of a school could influence the level of type and the condition of facilities available. Newly established schools could lack some of the basic facilities while established schools could have more than the average schools in terms of their condition of facilities. 
This study also sought to establish whether significant differences existed in secondary school principals' perceived competence levels in school finances based on school categories (private, district and provincial secondary schools). The findings were as reflected in Table 6 :

Table 6: Analysis of principals' perceptions of their levels of competence in school finances based on school categories

\begin{tabular}{|c|l|r|l|l|l|}
\hline $\begin{array}{c}\text { Management } \\
\text { of school } \\
\text { finances }\end{array}$ & $\begin{array}{l}\text { Sum of } \\
\text { Squares }\end{array}$ & $\begin{array}{l}\text { Degrees } \\
\text { of free- } \\
\text { dom (df) }\end{array}$ & $\begin{array}{l}\text { Mean } \\
\text { Square }\end{array}$ & Fig & \\
\hline $\begin{array}{c}\text { Between } \\
\text { Groups }\end{array}$ & 2450.522 & 2 & 1225.261 & 68.718 & 000 \\
\hline $\begin{array}{c}\text { Within } \\
\text { Groups }\end{array}$ & 1907.846 & 107 & 17.830 & & \\
\hline Total & $\mathbf{4 3 5 8 . 3 6 7}$ & $\mathbf{1 0 9}$ & & & \\
\hline
\end{tabular}

From Table 6, the obtained F value (68.718) was greater than the critical value 3.07 with 2 and 107 degrees of freedom (df) at 5 percent level of significance. As such, this study held that significant differences existed in management of school finances among school categories. The findings were also supported by the group means, 
which were as follows: private schools (64.8571) district schools (73.9048) and provincial schools (78.1587). Levels of administrative experience, the available facilities, school culture reflected in open communication systems could be responsible for differences in group means based on school categories.

A related objective sought to determine whether significant differences existed in management of school finances based on principals' exposure to leadership development programmes by KEMI. The comparison of the two-tailed t-test was tabulated as shown below:

Table 7: T-test for equality of means in management of school finances based on exposure (or lack of exposure) to leadership development programmes

\begin{tabular}{|c|c|c|c|c|c|c|c|}
\hline \multirow{2}{*}{$\begin{array}{c}\text { Manage- } \\
\text { ment of } \\
\text { school } \\
\text { finances }\end{array}$} & \multicolumn{5}{|c|}{ t-test for Equality of Means } & \multicolumn{2}{|c|}{$\begin{array}{l}95 \% \text { Confidence Inter- } \\
\text { val of the Difference }\end{array}$} \\
\hline & & & $\begin{array}{l}\text { Sig. } \\
(2- \\
\text { tailed) }\end{array}$ & $\begin{array}{l}\text { Mean } \\
\text { Differ- } \\
\text { ence }\end{array}$ & $\begin{array}{l}\text { Std. } \\
\text { Error } \\
\text { Differ- } \\
\text { ence }\end{array}$ & Lower & Upper \\
\hline $\begin{array}{c}\text { Equal } \\
\text { vari- } \\
\text { ances } \\
\text { assumed }\end{array}$ & $\begin{array}{l}-9.341 \\
\end{array}$ & 08 & .000 & -10.5195 & 1.12618 & -12.75177 & -8.28719 \\
\hline
\end{tabular}


The findings from Table 7 above indicate that the calculated t value (9.341) is greater than the tabulated t value (1.980). Hence, significant differences existed in management of school finances between schools under principals exposed to leadership development programmes by Kenya Education Management Institute (KEMI) and those who lacked such exposure. The findings are in agreement with the group means. The next section compares the overall ratings of principals in aspects of educational management compared by school categories and exposure to leadership development programmes by KEMI:

Table 8: A comparison of schools' overall rating by study variables:

\begin{tabular}{|c|c|c|c|c|c|c|c|c|}
\hline & \multicolumn{6}{|c|}{$\begin{array}{l}\text { Range of scores compared by study vari- } \\
\text { ables: }\end{array}$} & \multirow[b]{2}{*}{ Total } & \multirow[b]{2}{*}{ Mean } \\
\hline & $\begin{array}{l}55.00- \\
59.99\end{array}$ & $\begin{array}{l}60.0 \\
0- \\
64.9 \\
9\end{array}$ & $\begin{array}{l}65.00- \\
69.99\end{array}$ & $\begin{array}{l}70.00- \\
74.99\end{array}$ & $\begin{array}{l}75.00- \\
79.99\end{array}$ & $\begin{array}{l}80.00- \\
84.99\end{array}$ & & \\
\hline $\begin{array}{l}\text { Private } \\
\text { Schools }\end{array}$ & $\begin{array}{l}2 \\
(100.0 \\
\%)\end{array}$ & $\begin{array}{l}9 \\
(60.0 \\
\%)\end{array}$ & $\begin{array}{l}7 \\
(20.6 \% \\
)\end{array}$ & $\begin{array}{l}1 \\
(4.8 \%)\end{array}$ & $\begin{array}{l}1 \\
(3.8 \%)\end{array}$ & $\begin{array}{l}0 \\
(.0 \%)\end{array}$ & $\begin{array}{l}20 \\
(18.2 \\
\%)\end{array}$ & 65.1777 \\
\hline $\begin{array}{l}\text { District } \\
\text { Schools }\end{array}$ & $0(.0 \%)$ & $\begin{array}{l}6 \\
(40.0 \\
\%) \\
\end{array}$ & $\begin{array}{l}27 \\
(79.4 \% \\
\end{array}$ & $\begin{array}{l}10 \\
(47.6 \\
\%) \\
\end{array}$ & $\begin{array}{l}2 \\
(7.7 \%)\end{array}$ & $\begin{array}{l}0 \\
(.0 \%)\end{array}$ & $\begin{array}{l}45 \\
(40.9 \\
\%) \\
\end{array}$ & 68.3064 \\
\hline $\begin{array}{l}\text { Provin- } \\
\text { cial } \\
\text { Schools }\end{array}$ & $0(.0 \%)$ & $\begin{array}{l}0 \\
(.0 \%)\end{array}$ & $0(.0 \%)$ & $\begin{array}{l}10 \\
(47.6 \\
\%)\end{array}$ & $\begin{array}{l}23 \\
(88.5 \\
\%)\end{array}$ & $\begin{array}{l}12 \\
(100.0 \\
\%)\end{array}$ & $\begin{array}{l}45 \\
(40.9 \\
\%)\end{array}$ & 77.1189 \\
\hline Total: & $\begin{array}{l}2 \\
(100.0 \\
\%)\end{array}$ & $\begin{array}{l}15 \\
(100 \\
.0 \%)\end{array}$ & $\begin{array}{l}34 \\
(100.0 \\
\%)\end{array}$ & $\begin{array}{l}21 \\
(100 . \\
0 \%)\end{array}$ & $\begin{array}{l}26 \\
(100 . \\
0 \%)\end{array}$ & $\begin{array}{l}12 \\
(100 . \\
0 \%)\end{array}$ & $\begin{array}{l}110 \\
(100 . \\
0 \%)\end{array}$ & 71.3427 \\
\hline
\end{tabular}


From Table 8, it is evident that differences existed based on school categories. The provincial schools and district schools principals rated themselves higher in different aspects of leadership and administrative task areas. The private schools had peripheral ratings of just being average. Similar ratings also emerged on comparison of principals' ratings in terms of those who were exposed to KEMI leadership development programmes and those who lacked such exposure.

The findings are presented in Table 9 .

Table 9: Principals' perceptions of the their overall management ratings compared by exposure to KEMI leadership development programmes

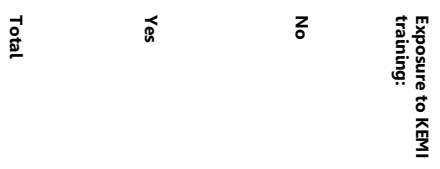

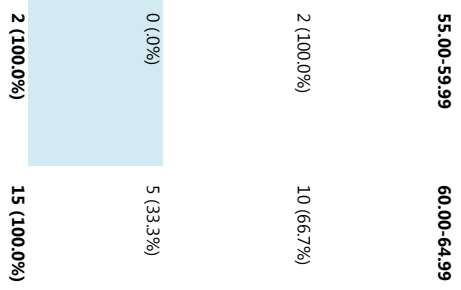

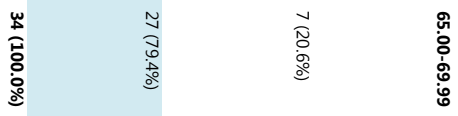

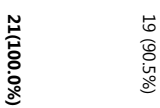

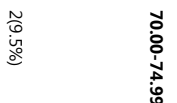

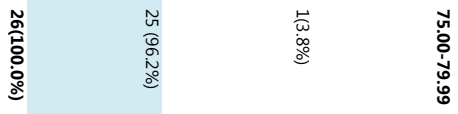

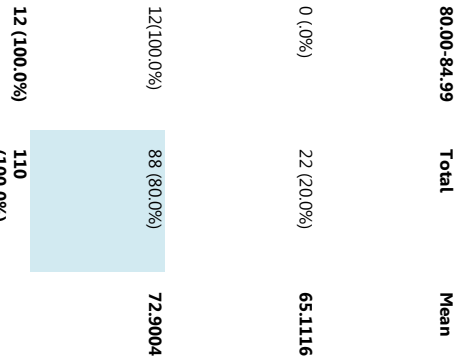


To determine whether the differences between principals' perceptions of their ratings in their administrative task areas were statistically significant, one-way Analysis of Variance was computed. The findings were as shown in the table 10.

Table 10: One-way Analysis of Variance on Overall principals' ratings in their administrative areas

Table 10 shows that schools' overall scores had differences based on categories and schools under principals exposed to in-service training as compared to those who had not been exposed to leadership development programmes by KEMI. The underlying reasons for the differences could be an interplay of institutional and principals' factors. Institutional factors could include such factors as the school category that mainly determine the level of staffing and the entry behaviour of the students admitted, the experience of the teaching staff, the number of administrative staff, their adminstrative experience among other variables that could influence institutional differences and principals' perceptions of their competence in their administrative task areas. 


\section{Conclusion}

This study found significant differences in principals' perceptions of their competence levels in curriculum and instruction, student personnel, school facilities and management of school finances. The findings were consistent across the task areas under investigation. Principals in different school categories (provincial, district and private schools) rated themselves in such a way that those exposed to KEMI leadership development programmes rated themselves higher than those who lacked such exposure. It was therefore concluded that categorisation of schools influenced the principals' perceptions of their levels of competence in governance of secondary schools. This was also evident from the $\mathrm{F}$ ratio as well as the sample means of all the three categories of schools compared. The comparison of the t-test in all the six criteria showed significant differences between schools under principals exposed to management training by Kenya Education Staff Institute (KESI) and those who lacked such exposure. 


\section{Recommendations on Policy and Practice}

i) This study found significant differences between principals exposed to KEMI leadership development programmes and those who lacked such exposure. Those principals who had such exposure scored higher in their rating of the academic performance of their schools as well as their own perceptions of their own competence. This study proposes that a study be conducted to determine the preferred leadership development approaches for acquisition of leadership competencies particularly for secondary school principals in an era of changing governance structures.

ii) Capacity building programmes for principals should incorporate among other aspects school -based planning, financial management, dealing with giftedness among students, management of human resources, schoolcommunity relations and labour legislation in relation to educational institutions. Such sensitisation and training programmes should seek to empower educational personnel at school levels to adopt pro-active approaches to 
their operations rather than being overdependent on external supervision by Ministry of Education officials.

\section{Suggestions for Further Research}

i) This study was confined to only two Counties of the country owing to limited funds and its nature of examining schools from a holistic view. In light of this, the efficacy of this study's findings can be tested by replicating it on a broader sample that cuts across different parts of the country or any other part of the world. Such a study can examine principals across the different regions of the country and include all categories of schools for a holistic and a more representative study that can give a true reflection of the situation in the whole of Kenya. Including of national schools would further shed light on the management practices in a broad spectrum of variables.

ii) This study also recommends a research to determine the efficacy of various staff development programmes, performance management and improvement strategies in both primary and secondary schools. This stems from the need to avoid making schools experimental grounds for all manner of educational management fads. 


\section{References}

Asunda, R. (1983). A study of secondary school principals' leadership styles on academic performance in Kenya certificate of education. (Unpublished master of education thesis). University of Nairobi, Nairobi.

Audit Commission. (1991). Management within primary school. London: The Audit Commission for Local Authorities and National Health Services in England \& Wales.

Austin, G. R. (1978). Exemplary schools and search for effectiveness. Journal of Educational Leadership.

Bell, L., \& Rhodes, C. (1996). Skills in primary school management. London: Routledge.

Campbell, R. F. Corbally, J. E., \& Nystrand, R. (1983). Introduction to educational administration (6th ed.). Boston: Allyn and Bacon, Inc.

Clark, D. L., \& Lotto, L. S. (1982). Principals in instructionally effective schools. Unpublished manuscript.

Onyango, G.A. (2001). Principals' competences and implications for pre-service and in-service education: A case of Nairobi Province and Kakamega District (Unpublished PhD Thesis). Kenyatta University, Nairobi. 
Dhaundiyal, D. C. (1989). The efficiency of institutional performance in intermediate colleges of Garhwal region (India). Unpublished $\mathrm{PhD}$ Thesis (Education), Hemvati Nandan Bahuguna Garhwali University.

Eshiwani, G. S. (1983). Factors Influencing performance among primary and secondary school pupils of Western Kenya. Nairobi: Kenyatta University, Bureau of Education Research and Publications (ERAP).

Esp, D. G. (1993). Competencies for school managers. London: Kogan Page.

Griffins, G. (1994). School mastery: Straight talk about boarding school management in Kenya. Nairobi: Lectern.

Hmaidan, M. M. (1991). The characteristics of effective schools in Jordan. Unpublished $\mathrm{PhD}$ dissertation. The University of Wisconsin: Dissertation Abstracts International 53 (02).

Kalai, J. M. (1998). Kenya Education Staff Institute (KESI) in-service programmes as perceived by secondary school principals: $A$ case study of Kitui District. Unpublished master of education thesis. University of Nairobi, Nairobi.

Kalra, A. (1997). Effective school management and role of school principals. New Delhi: APH Publishing Corporation. 
Karani, F. A. et al. (1995). Cost and financing of education in Kenya: Access, quality and equity in secondary school education. Nairobi: Ministry of Education and World Bank.

Kenya Education Staff Institute (2006). Training budgetary estimates for Kenya Education Staff Institute. Nairobi: Unpublished Report.

Kerlinger, F. N. (1986). Foundation of behavioural research. Holt: Renehasl and Watson.

Koech, A. (1994). Assessing professional and development needs of secondary school principals in Kenya: A study involving Kericho district schools. Unpublished master of arts thesis. Dalhousie University, Halifax.

Kombo, D. $K \&$ Tromp, D. L .A. (2006). Proposal and Thesis Writing: An Introduction. Nairobi, Paulines Publications Africa.

Machura, S. S. (1991). The indicators of effectiveness in senior high schools. Unpublished PhD Dissertation. University of Alberta in Dissertation Abstracts International-53, (08).

Mary, M. T. (1990). An appraisal of educational institutions (schools) run by the society of Jesus, Mary and Joseph in Andra-Pradesh. Unpublished $\mathrm{PhD}$ (Education) thesis. The Maharaja Sayajirao University of Baroda. 
Mbiti, D. M. (2007). Foundations of school administration. Nairobi: Oxford Press.

Morumbasi, M. C. (1993). A study of Kenya secondary school principals' perceptions of the effectiveness of KESI in-service programme. Unpublished Master of Arts Thesis. Lake Head University, Ontario.

Mugenda, O. M., \& Mugenda, A. G. (2003). Research methods: Quantitative and qualitative approaches. Nairobi: Acts Press.

Njuguna, F. W. (1998). A Study of principals' leadership styles and students' Kenya certificate of secondary school examination performance in public secondary schools in Nairobi province. Unpublished master of education Thesis. University of Nairobi, Nairobi.

Nxumalo, A. (1992). Relationship of school management and pupils' achievement - The Swaziland experience. In Basic Education Forum 2. Nairobi: Bureau of Educational Research, Kenyatta University.

Okoth, U. A. (2000). A study of effects of leadership styles on Kenya certificate of secondary education performance in Nairobi province, Kenya. Unpublished M.Ed thesis. University of Nairobi, Nairobi.

Onyango, G. A. (2001). Competencies needed by secondary school principals and implications for pre-service and in-service education: A case 
of Nairobi Province and Kakamega District. Unpublished $\mathrm{PhD}$ thesis. Kenyatta University, Nairobi.

Owens, G. R. (1991). Organisational behaviour in educational (4th ed.). New Jersey, Englewood Cliffs: Prentice-Hall.

Republic of Kenya, Ministry of Education, Science and Technology. (1999). Report on totally integrated quality education and training (TIQET) Nairobi: Government Printer.

Republic of Kenya (1998). Master plan on Education and training. Nairobi: Ministry of education and human resource development. Nairobi: Jomo Kenyatta Foundation.

Republic of Kenya (1988). Ministry of Education, Kenya Education Staff Institute (KESI) Legal Notice No. 565. Nairobi: Government Printer.

Republic of Kenya. (1988). Sessional paper No. 6 on education and manpower training for next decade and beyond, (Kamunge Report). Nairobi: Government Printer.

Stedman, L. C. (November, 1987). It's the Time we changed the effective schools' formula. Phi Delta Kappa, 215-224 in Onyango, G. A. (2001). Competencies needed by secondary school principals and implications for pre-service and in-service education: A case of Nairobi province and Kakamega district. Unpublished $\mathrm{PhD}$ thesis, Kenyatta University, Nairobi. 
Upasani, N. K., Chaudury, K., Deshpande, V. S. \& Karte, S. S. (1991). A study of models of efficient and inefficient administration and management at secondary school level in Pune district. An independent study, Pune, Adharsha comprehensive college of education and Research. In Fifth Survey of Educational research (1997). Trend reports Volume II (1988-1992). New Delhi: NCERT.

Vyhmeister, N. J. (2001). Your indispensable guide to writing quality research papers. Michigan: Zondervan.

Wachira, J. N. (1996). Preparation secondary school principals and implications on their administrative performance: A case of Nairobi Province. Unpublished master of education thesis. Kenyatta University, Nairobi. 